\title{
IMPLEMENTASI KURIKULUM 2013 DALAM KEGIATAN PEMBELAJARAN PENDIDIKAN AGAMA ISLAM DI SEKOLAH MENENGAH KEJURUAN NEGERI 13 MALANG
}

\author{
Subhan Adi Santoso, Idzi’ Layyinnati, M.Chotibuddin \\ Dosen Sekolah Tinggi Ilmu Tarbiyah Muhammadiyah Paciran. Lamongan \\ Email: h_ans84@yahoo.com,idziela@gmail.com, \\ boedz2012@gmail.com
}

\begin{abstract}
Curriculum 2013 consisting of goals, structure and curriculum, educational calendar and syllabus. Islamic religious education, this time religious teachers should be aware that there are four trends that will be faced by religion and is a challenge for religious people as follows: internal diversity, diversity of structural, cultural diversity, criticism of science. The author will choose a location study at Vocational High School 13 Malang, the subject of his research is the principal, vice principal part of the curriculum, Islamic religious education teachers, and students. In this study the authors used three kinds of data collection techniques are methods of observation, interviews, documentation methods. The results of the study as follows: 1. Planning Islamic Religious Education Learning is a teacher before committing learning activities in the classroom should be made syllabus and lesson plans. 2. Implementation of Islamic Religious Education Learning is the implementation phase for the design drawn up plans for teachers. 3. Evaluation of Islamic Religious Education Learning is a measuring instrument to measure the achievement of objectives.
\end{abstract}

Keywords: Curriculum 2013, learning Islamic education

Istilah "kurikulum" berasal dari bahasa latin, yakni "curriculae" artinya jarak yang harus ditempuh oleh seorang pelari. Pada waktu itu, pengertian kurikulum ialah jangka waktu pendidikan yang harus ditempuh oleh siswa yang bertujuan untuk memperoleh ijazah. (Susilo, 2007: 77)

Sedangkan Kurikulum 2013 adalah kurikulum operasional yang disusun oleh dan dilaksanakan di masing-masing satuan pendidikan. Kurikulum 2013 terdiri dari tujuan pendidikan, struktur dan muatan kurikulum, kalender pendidikan, dan silabus. ( Tim Pustaka Yustisia, 2007:146)

Menurut Muhaimin yang mengutip dari Bambang Pranowo dalam konteks pendidikan agama Islam, saat ini guru agama harus sadar bahwa ada empat trend yang akan dihadapi oleh agama dan sekaligus merupakan tantangan bagi umat beragama sebagai berikut:
1. Keragaman intenal (internal diversity)

2. eragaman struktural (structural differencial)

3. Kemajemukan budaya (cultural pluralism)

4. Kritik ilmu pengetahuan terhadap penjelasan agama yang masih konvensionaltradisional (scientific criticism). Keempat trend ini akan berimplikasi pada pengembangan kurikulum pendidikan agama Islam pada semua jenjang pendidikan.

Muhaimin, 2004:102)

Salah satu komponen penting dari sistem pendidikan tersebut adalah kurikulum, karena kurikulum merupakan komponen pendidikan yang dijadikan acuan oleh setiap satuan pendidikan, baik oleh pengelola maupun penyelenggara; khususnya oleh guru dan kepala sekolah. ( Mulyasa, 2004:4). 
Kurikulum 2013, sebagai suatu konsep dan sekaligus sebagai sebuah program, yang memiliki cirri-ciri sebagai berikut:

1. Menekankan pada ketercapaian siswa baik secara individual maupun klasikal

2. Berorientasi pada hasil dan keberagaman

3. Penyampaian dalam pembelajaran menggunakan pendekatan dan metode yang bervariasi

4. Sumber belajar bukan hanya guru tetapi sumber belajar lainnya yang memenuhi unsur edukatif

5. Penilaian menekankan pada proses dan hasil belajar dalam upaya penguasaan suatu kompetensi. (Haryati, 2009:5)

Dari sini penulis akan mengangkat sebuah masalah yang mana kurikulum pendidikan di negeri ini kerap kali berubah-ubah, menyebabkan buku tidak lagi dimanfaatkan. Belum selesai kurikulum A, sudah diganti dengan kurikulum B, belum selesai dilaksanakan kurikulum B sudah berganti lagi dengan kurikulum C. yang terakhir, kurikulum baru yang dinamakan K-13 (kurikulum 2013) untuk menggantikan sistem KTSP (kurikulum tingkat satuan pendidikan) yang diterapkan sebelumnya. Sehingga banyak guru yang masih gagap untuk menyusun bahan ajar sendiri untuk memenuhi kompetensi yang diharapkan.(www.citizennews.suaramerde ka.com. 28-05-2008)

Berdasarkan pada fenomena, maka dalam penulisan, penulis tertarik untuk mengambil judul Implementasi Kurikulum 2013 Dalam Kegiatan Pembelajaran Pendidikan Agama Islam Di Sekolah Menengah Kejuruan Negeri 13 Malang.

Berdasarkan uraian latar belakang yang telah dikemukakan di atas, maka penulis dapat merumuskan permasalahan pokok sebagai berikut:
Bagaimana

implementasi

kurikulum 2013 dalam kegiatan pembelajaran pendidikan agama Islam di Sekolah Menengah Kejuruan Negeri 13 Malang.

Ingin memperoleh gambaran implementasi kurikulum 2013 dalam kegiatan pembelajaran pendidikan agama Islam di Sekolah Menengah Kejuruan Negeri 13 Malang

\section{Kajian Teori}

Penelitian terdahulu yang dilakukan oleh saudara Rina Rohdotul Jannah dengan judul Kurikulum 2013 Pendidikan Agama Islam dan Budi Pekerti (Analisis Implementasi Pada Kelas X SMAN I Pakem Sleman Yogyakarta) pada tahun 2014. Penelitian ini memiliki tujuan dasar untuk membahas seputar kajian manajemen dalam implementasi Kurikulum 2013, artinya kajian penelitian ini lebih luas dari penelitian sebelumnya, tidak hanya terpusat dalam mata pelajaran PAI dan Kebudayaan, melainkan semua aspek dalam kurikulum, mulai dari perencanaan kurikulum, pengorganisasian kurikulum, implementasi kurikulum hingga evaluasi dalam kurikulum.

Kurikulum adalah seperangkat rencana dan peraturan mengenai isi dan bahan pelajaran serta cara yang digunakan sebagai pedoman penyelenggara kegiatan belajar-mengajar. Kurikulum memuat isi dan materi pelajaran. Kurikulum adalah sejumlah mata ajaran yang harus ditempuh dan dipelajari oleh siswa untuk memperoleh sejumlah pengetahuan. Mata ajaran dipandang sebagai pengalaman orang tua atau orang-orang pandai masa lampau, yang telah disusun secara sistematis dan logis.

Kurikulum sebagai pengalaman belajar. Dalam hal ini kurikulum merupakan serangkaian pengalaman belajar. Menurut Romine yang dikutip oleh Hamalik sebagai berikut: Curriculum is 
interpreted to mean all of the organized courses, activities, and experiences which pupils have under direction of the school, whether in the class room or not.( Mulyasa, 2004:17-18)

Kurikulum 2013 adalah kurikulum operasional yang disusun oleh dan dilaksanakan di masing-masing satuan pendidikan. Kurikulum 2013 terdiri dari tujuan pendidikan tingkat satuan pendidikan, kalender pendidikan dan silabus.

Pembelajaran ialah membelajarkan siswa menggunakan asas pendidikan maupun teori belajar, yang merupakan penentu utama keberhasilan pendidikan. Pembelajaran merupakan proses komunikasi dua arah, mengajar dilakukan oleh pihak guru sebagai pendidik, sedangkan belajar dilakukan oleh peserta didik atau murid. Dalam pengertian demikian dapat dikatakan bahwa pembelajaran adalah upaya membelajarkan siswa untuk belajar. Kegiatan ini akan mengakibatkan siswa mempelajari sesuatu dengan cara lebih efektif dan efisien.

Pembelajaran terkait dengan bagaimana (how to) membelajarkan siswa atau bagaimana membuat siswa dapat belajar dengan mudah dan terdorong oleh kemauannya sendiri untuk mempelajari apa (what to) yang teraktualisasikan dalam kurikulum sebagai kebutuhan (needs). Karena itu, pembelajaran berupaya menjabarkan nilai-nilai yang terkandung di dalam kurikulum dengan menganalisis tujuan pembelajaran dan karakteristik isi bidang studi pendidikan agama yang terkandung di dalam kurikulum. Selanjutnya, dilakukan kegiatan untuk memiliki, menetapkan, dan mengembangkan, cara-cara atau strategi pembelajaran yang tepat untuk mencapai tujuan pembelajaran yang ditetapkan sesuai kondisi yang ada, agar kurikulum dapat diaktualisasikan dalam proses pembelajaran sehingga hasil belajar terwujud dalam diri peserta didik.
Tujuan pembelajaran merupakan salah satu aspek yang perlu dipertimbangkan dalam merencanakan pembelajaran. Sebab segala kegiatan pembelajaran muaranya pada tercapainya tujuan tersebut.

Tujuan pembelajaran adalah pernyataan tentang hasil pembelajaran atau apa yang diharapkan. Tujuan ini bisa sangat umum, sangat khusus, atau dimana saja dalam kontinum umum-khusus. Karakteristik bidang studi adalah aspekaspek suatu bidang studi yang dapat memberikan landasan yang berguna sekali dalam mendiskripsikan strategi pembelajaran, seperti misalnya, waktu, media, personalia, dan dana/uang.

\section{Metode Penelitian}

Penulis akan memilih lokasi penelitian pada Sekolah Menengah Kejuruan Negeri 13 Malang, tepatnya di Perumahan Villa Bukit Tidar No 13 kota Malang.

Adapun subyek penelitiannya adalah kepala sekolah yaitu ibu husnul chotimah, M.Pd, Waka kurikulum, guru PAI, dan siswa

Penelitian ini menggunakan pendekatan berparadigma DeskriptifKualitatif. Penelitian ini bertujuan untuk menggambarkan realitas empiris sesuai fenomena secara rinci dan tuntas, serta untuk mengungkapkan gejala secara holistis kontekstual melalui pengumpulan data dari latar alami dengan memanfaatkan diri peneliti sebagai instrumen kunci.

Dalam penelitian ini penulis menggunakan tiga macam teknik pengumpulan data yaitu metode observasi atau pengamatan, metode wawancara, metode dokumentasi. 


\section{Paparan Dan Pembahasan Data Hasil Penelitian}

Hasil temuan penelitian yang telah diperoleh penulis sebagai berikut:

Sebagimana data yang diperoleh dilapangan, kebijakan yang ada di SMKN 13 Malang ini adalah, dalam pembelajaran pendidikan agama Islam yang siswanya diarahkan pada kegiatan-kegiatan keagamaan sebelum memulai pelajaran. Yaitu siswa diwajibkan melaksanakan shalat dhuha yang telah dijadwal oleh sekolah, kemudian yang lain diwajibkan membaca Al-qur'an bersama-sama sebelum kegiatan pembelajaran berlangsung.

Dari data yang diperoleh dilapangan, di dalam membuat perencanaan pembelajaran pendidikan agama Islam dalam implementasi Kurikulum 2013 tidak ada perencanaan yang bersifat khusus yang dipersiapkan untuk itu, yang mana seorang guru merencanakan kegiatan pembelajaran sesuai dengan RPP yang dibuat dan langsung diaplikasikannya di dalam kelas.

Perencanaan merupakan proses penyusunan sesuatu yang akan dilaksanakan untuk mencapai tujuan yang telah ditentukan. Pelaksanaan perencanaan tersebut dapat disusun berdasarkan kebutuhan dalam jangka tertentu sesuai dengan keinginan pembuat perencanaan. Namun yang lebih utama adalah perencanaan yang dibuat harus dapat dilaksanakan dengan mudah dan tepat sasaran.

Dalam kegiatan pembelajaran pendidikan agama Islam di SMKN 13 Malang ini berjalan sebagaimana biasanya (seperti yang telah direncanakan). Dari data yang diperoleh di lapangan ternyata siswa banyak yang merasa senang terhadap pembelajaran yang ada, karena disamping pelajaran agama yang ada dapat menambah dan mempertebal keimanan siswa. Karena siswa senang dengan metode yang dipakai oleh guru selama dalam kegiatan pembelajaran berlangsung di dalam kelas.

Dalam penyampaian materi pendidikan agama islam, guru yang ada selalu mengaitkan dengan fenomena/kejadian yang ada. Hal ini dilakukan dalam rangka mengarahkan peserta didik agar peduli terhadap lingkungan sekitarnya.

Seorang guru untuk mengetahui hasil yang telah diperoleh terkait dengan apa yang telah ditransformasikan kepada anak didiknya, serta untuk mengetahui apakah tujuan tercapai atau belum, dan juga berapa persen tercapainya. Guru tadi telah membuat cara mengevaluasi, yaitu cara mengukur kemampuan murid setelah proses belajar mengajar selesai.

Evaluasi yang dilakukan tergantung dari kurikulum yang dipakai, sedangkan kurikulum yang dipakai adalah Kurikulum 2013, maka yang dijadikan bahan evaluasi harus memperhatikan ketiga ranah, yaitu: kognitif (pengetahuan), afektif (sikap) dan psikomotor (keterampilan).

Ketiga ranah ini sebaiknya dinilai secara proporsional sesuai dengan sifat mata pelajaran yang bersangkutan. Sebagai contoh pada mata pelajaran pendidikan agama Islam, aspek yang dinilainya harus menyeluruhdengan memperhatikan tingkat perkembangan siswa serta bobot setiap aspek dari setiap kompetensi dan materi. Misalnya aspek kognitif meliputi seluruh materi pembelajaran (Al-Qur'an, Akhlak dan Ibadah), afektif sangat dominan pada materi pelajaran akhlak dan aspek psikomor dan pengalaman sangat dominan pada materi pelajaran ibadah dan membaca Al-Qur'an. 


\section{Kesimpulan Dan Saran}

\section{Kesimpulan}

Kesimpulan yang bisa diambil dari Implementasi Kurikulum 2013 Dalam Kegiatan Pembelajaran Pendidikan Agama Islam ini adalah sebagai berikut:

1. Perencanaan Pembelajaran Pendidikan Agama Islam adalah guru sebelum melakukan kegiatan pembelajaran di dalam kelas haruslah membuat silabus dan RPP.

2. Pelaksanaan Pembelajaran Pendidikan Agama Islam adalah tahap penerapan atas desain perencanaan yang telah dibuat guru.

3. Evaluasi Pembelajaran Pendidikan Agama Islam adalah alat ukur untuk mengukur ketercapaian tujuan.

\section{Saran}

diharapkan untuk penulis yang akan datang dapat melengkapi kekurangan penulis pada penelitian ini. karena sesungguhnya penelitian ini jauh dari kata sempurna. Dan diharapkan penelitian yang akan datang dapat mendapatkan hasil implementasi kurikulum 2013 yang lebih sempurna

\section{DAFTAR RUJUKAN}

Arikunto, Suharsimi. 2002 Prosedur Penelitian Suatu Pendekatan Praktek: Edisi Revisi V Jakarrta Rineka Cipta.

Dakir. 2004. Perencanaan dan Pengembangan Kurikulum. Jakarta: PT Rineka Cipta.
Hamalik, Oemar. 2008. Kurikulum dan Pembelajaran. Jakarta: PT Bumi Aksara.

Haryati, Mimin. 2009. Model \& Teknik Penilaian Pada Tingkat Satuan Pendidikan. Jakarta: Gaung Persada Press

Muhaimin. 2004. Paradigma Pendidikan Islam Bandung: PT Remaja Rosdakarya.

Mulyasa, E. 2004. Kurikulum Tingkat Satuan Pendidikan Bandung: PT Remaja Rosdakarya.

Poedjiadi, Anna. 2005. Sains Teknologi Masyarakat : Model Pembelajaran Kontekstual Bermuatan Nilai. Bandung: PT Remaja Rosda Karya dan Program Pascasarjana Universitas Pendidikan Indonesia.

Susilo, Muhammad, Joko. 2007. Kurikulum Tingkat Satuan Pendidikan Manajemen Pelaksanaan Dan Kesiapan Sekolah Menyongsongnya Yogyakarta: Pustaka Pelajar.

Sukmadinata, Nana, Syaodih. 2008. Pengembangan Kurikulum Teori dan Praktek. Bandung: PT Remaja Rosdakarya.

Tim Pustaka Yustisia. 2007. Panduan Lengkap Kurikulum Tingkat Satuan Pendidikan Yogyakarta: Pustaka Yustisia.

UU RI Nomor 20 tahun 2003 Tentang SISDIKNAS. 2003. Bandung: Citra Umbara.

www.citizennews.suaramerdeka.com. 2008 